\title{
PENGEMBANGAN PERANGKAT PEMBELAJARAN BERBASIS INKUIRI TERBIMBING MENGGUNAKAN SIMULASI PhET UNTUK MEREDUKSI MISKONSEPSI SISWA
}

\author{
Soelastri Kohar ${ }^{1)}$, Budi Jatmiko ${ }^{2)}$, Raharjo ${ }^{\text {3) }}$ \\ 1) Program Studi Pendidikan Sains, Pascasarjana Universitas Negeri Surabaya \\ ${ }^{2)}$ Dosen Program Studi Pendidikan Sains, Pascasarjana, Universitas Negeri Surabaya \\ ${ }^{3)}$ Dosen Program Studi Pendidikan Sains, Pascasarjana, Universitas Negeri Surabaya
}

\begin{abstract}
The purpose of this research is to develop a guided inquiry-based learning device by using a simulation program PhET eligible to reduce misconceptions students. The development of instructional materials use 4-D model which was reduced to 3-D and tried out in the eleventh grade of SMAN 4 Surabaya in academic year of 2015/2016 useing one group pretest-posttest design. The data was collected through observation, test, and questionnaire. The data was analysis by quantitative-qualitative descriptive. The results were analyzed and obtained several findings: (1) The validity include: (a) Validation RPP either category, BAS good enough category, LKS either category, the Test misconception is generally valid; $(B)$ average legibility BAS amounted to $59.8 \%$ and amounted to $71.3 \% \mathrm{LKS} ;(C)$ Average level of difficulty BAS $32.5 \%$ and LKS 34.3\%; (2) Practicality include: (a) learning tools categorized in terms of enforceability RPP good, and (b) The level of activity of students considered good (3) Effectiveness which includes: (a) the test results of misconceptions with $N(\mathrm{~g}) 0.73$; and the results of statistical test analysis of one-way ANOVA, namely: 1) there was no significant difference decrease misconceptions of third grade, 2) $N$-Gain decrease misconceptions students experienced in each class (b) The response of students to the lecture are positive. Based on the findings in this study, it is concluded the dynamic power of learning with guided inquiry model is properly used by high school students to reduce misconceptions students.
\end{abstract}

Key words: Misconceptions, Simulation PhET, Guided Inquiry

\begin{abstract}
Abstrak: Penelitian ini bertujuan untuk mengembangkan perangkat pembelajaran berbasis inkuiri terbimbing dengan menggunakan program simulasi PhET yang layak untuk mereduksi miskonsepsi siswa. Pengembangan perangkat pembelajaran menggunakan model 4-D yang direduksi menjadi 3-D dan diujicobakan di tiga kelas XI SMAN 4 Surabaya tahun pelajaran 2015/2016 dengan one group pretest posttest design. Pengumpulan data menggunakan observasi, tes, dan angket.Data dianalisis menggunakan deskriptif kualitatif dan kuantitatif. Temuan penelitian yaitu: (1) Validitas: (a) Validasi RPP kategori baik, BAS kategori cukup baik, LKS kategori baik, Tes Uji Miskonsepsi umumnya valid; (b) Rata-rata keterbacaan BAS sebesar 59,8\% dan LKS sebesar 71,3\%; (c) Rata-rata tingkat kesulitan BAS sebesar 32,5\% dan LKS sebesar 34,3\%; (2) Kepraktisan meliputi: (a) Perangkat pembelajaran ditinjau dari keterlaksanaan RPP berkategori baik, dan (b) Tingkat aktivitas siswa dikategorikan baik (3) Keefektifan yang meliputi: (a) hasil tes uji miskonsepsi dengan $\mathrm{N}(\mathrm{g})$ 0,73; dan hasil analisis uji statistik one-way ANOVA, yaitu : 1) tidak ada perbedaan yang signifikan penurunan miskonsepsi dari ketiga kelas, 2) N-Gain penurunan miskonsesi siswa dialami pada masing-masing kelas (b) Respon siswa terhadap KBM adalah positif. Berdasarkan hasil temuan dalam penelitian ini, disimulkan bahwa perangkat pembelajaran listrik dinamis dengan model inkuiri terbimbing layak digunakan oleh siswa SMA untuk menurunkan miskonsepsi siswa.
\end{abstract}

Kata-kata Kunci:Miskonsepsi, Simulasi PhET, Inkuiri Terbimbing

\section{PENDAHULUAN}

Pemerintah telah mempercepat pencanangan Millenium Development Goals, yang semula dicanangkan tahun 2020 dipercepat menjadi 2015. Millenium Development Goals adalah era pasar bebas atau era globalisasi, sebagai era persaingan mutu atau kualitas, siapa yang berkualitas dialah yang akan maju dan mampu mempertahankan eksistensinya. Oleh karena itu, pembangunan sumber daya manusia (SDM) berkualitas merupakan suatu keniscayaan yang tidak dapat ditawar-tawar lagi. Hal ini mutlak diperlukan, karena akan menjadi penopang utama pembangunan nasional yang mandiri dan berkeadilan, good governance and clean governance; serta menjadi jalan keluar bagi bangsa Indonesia dari multidimensi krisis, kemiskinan, dan kesenjangan ekonomi (Mulyasa; 2011: 2).

Pendidikan memegang peranan yang sangat penting dalam proses peningkatan kualitas sumber daya manusia. Peningkatan kualitas pendidikan merupakan suatu proses yang terintegrasi dengan proses peningkatan kualitas sumber daya manusia itu sendiri. Pendidikan merupakan faktor penentu masa depan suatu bangsa. Berbagai usaha pembenahan 
sistem pendidikan dan perangkatnya di Indonesia terus dilakukan untuk memacu bidang pendidikan agar maju dan berkembang sesuai dengan perkembangan ilmu dan teknologi.

Fisika merupakan salah satu bagian dari IPA (sains) yang berpengaruh cukup besar dalam menunjang pembangunan dan kemajuan teknologi.Betapa pentingnya peranan fisika, maka tugas guru-guru fisika mengembangkan pengetahuan tentang fisika dan penerapannya.

Guna memenuhi tujuan tersebut, maka pemerintah dan beberapa instansi nonpemerintah terus berusaha memajukan pendidikan fisika di SMA/MA.Namun sebagian besar siswa masih takut dengan fisika. Hal ini terlihat dari hasil rata-rata ujian nasional fisika hasilnya belum sangat memuaskan (Suparno;2008:1).

Guna mengetahui sejauh mana siswa memahami konsep, maka pada bulan April 2013 peneliti mengadakan wawancara untuk beberapa siswa setelah itu mengadakan tes objektif beralasan sebagai penelitian pendahuluan pada sejumlah siswa kelas XI. Jenis tes objektif yang digunakan tes multiple choice dengan 4 pilihan jawaban dan satu pilihan jawaban terbuka serta harus memberikan alasan jawabannya tersebut disertai dengan Certainty of Response Indek (CRI).

Hasil dari wawancara dan tes objektif beralasan diperoleh bahwa banyak terjadi miskonsepsi pada siswa untuk pokok bahasan listrik dinamis. Menggambarkan pemasangan voltmeter dan amperemeter pada rangkaian sederhana siswa yang menjawab benar $40 \%$ (15 anak), dan siswa yang menjawab salah 60\% (23 anak). Lampu-lampu yang memiliki daya dan tegangan yang sama dirangkai seri, siswa yang menjawab benar 26,3\% (10 anak), dan siswa yang menjawab salah $73,7 \%$ (28 anak). Siswa menjelaskan terangnya lampu bergantung pada letaknya terhadap baterai, semakin dekat dengan baterai maka semakin terang lampu tersebut, semakin jauh dari baterai semakin redup. Padahal menurut teori fisika, lampu itu akan menyala sama terangnya. Demikian juga dalam menentukan ada tidaknya tegangan pada suatu rangkaian yang terbuka. Siswa yang menjawab benar $8 \%$ (3 anak), dan siswa yang menjawab salah 92\% (35 anak). Siswa beranggapan tegangan hanya terjadi dalam suatu rangkaian tertutup, bila ada suatu rangkaian terbuka yang dihubungkan dengan baterai, maka tidak ada tegangan didalam rangkaian tersebut.Hasil tersebut diperoleh pada saat guru masih menerapkan pembelajaran secara konvensional yaitu penyampaian materi masih dilaksanakan dengan metode ceramah saja.

Penyebab miskonsepsi fisika yang dialami siswa bisa berasal dari konsep awal atau prakonsepsi sebelum siswa mengikuti pelajaran formal, atau disebabkan adanya pemikiran humanistik, yaitu tingkah laku benda dipahami seperti tingkah laku manusia yang hidup sehingga tidak cocok. Serta disebabkan oleh reasoning penalaran siswa yang tidak lengkap atau salah. Kesalahan konsep atau miskonsepsi Fisika dapat berasal dari persepsi yang diterima siswa tidak sama dengan persepsi guru yang memberikan materi, kesalahan pemahaman bahan ajar yang disampaikan guru, atau interaksi antara siswa dengan buku pegangan. Buku teks (buku pegangan) yang digunakan terlalu sulit bagi level siswa yang sedang belajar dapat juga menumbuhkan miskonsepsi karena siswa sulit menangkap isinya,(Suparno; 2005).

Guna menelusuri miskonsepsi siswa dalam penelitian ini menggunakan bantuan Certainty of Response Indek (CRI) sehingga terungkap jawaban yang lucky guess (menjawab benar dengan menebak), a lack of knowledge (kekurangan pengetahuan), miskonsepsi, dan yang benar-benar memahami konsep. Setelah menggunakan CRI, kemudian dilanjutkan dengan interview, interview dilakukan dengan maksud untuk mempertegas hasil yang diperoleh melalui CRI dan lebih menekankan pada bentuk miskonsepsi yang spesifik terhadap konsep listrik dinamis.

Berpijak dari permasalahan di atas, maka pembelajaran baru dapat dikatakan dalam kondisi yang berhasil jika dapat melampaui batas terendah secara signifikan. Untuk dapat melampaui target, maka sistem pembelajaran harus diubah dengan pembelajaran yang lebih inovatif, kreatif, menarik, menyenangkan serta mampu memberikan penanaman konsep yang maksimal kepada siswa. Solusi yang dapat dilakukan guru untuk memperbaiki proses pembelajaran adalah dengan menggunakan pendekatan belajar yang tepat serta strategi pembelajaran yang inovatif. Salah satu pendekatan pembelajaran yang dapat diterapkan adalah dengan inkuiri. 
Inkuiri merupakan proses bertahap, bertingkat, dan berkesinambungan. Model pembelajaran inkuiri terbimbing disarankan oleh Wenning (2005) untuk diterapkan agar menjembatani inquires pemula agar terbiasa dengan pembelajaran inkuiri. Menurut Wenning (2005).

Materi listrik dinamis selain merupakan materi dasar yang perlu dipahami oleh peserta didik juga merupakan materi yang bersifat abstrak seperti pergerakan elektron pada listrik dinamis, sehingga materi listrik dinamis merupakan sala satu pelajaran fisika yang dianggap sukar dipahami oleh peserta didik. Salah satu media pembelajaran bagi mata pelajaran fisika adalah simulasi virtual lab. Salah satu virtual lab PhET yang tersedia adalah PhET dengan judul Circuit Construction kit $(A C+D C)$. Dengan adanya virtual lab PhET Circuit Construction kit $(A C+D C)$, diharapkan dapat membantu siswa dalam mempelajari konsep listrik dinamis, karena terdapat simulasi-simulasi, dan game dimana siswa dapat mencoba sendiri. Konsep-konsep listrik dinamis yang terdapat dalam PhET Circuit Construction kit $(A C+D C)$ antara lain terangnya beberapa lampu yang dirangkai seri, besarnya arus yang mengalir dalam rangkaian seri maupun paralel, besarnya tegangan pada rangkaian seri maupun paralel dan sebagainya.

Berdasarkan uraian latar belakang, maka dilakukan peneliti yang dapat mewujudkan kelayakan perangkat pembelajaran berintegrasi pada PhET dengan judul: "Pengembangan perangkat pembelajaran berbasis inkuiri terbimbing dengan menggunakan program simulasi PhET untuk mereduksi Miskonsepsi Siswa".

\section{METODE PENELITIAN}

\section{A. Jenis Penelitian}

Penelitian ini termasuk jenis penelitian pengembangan karena mengembangkan perangkat pembelajaran yang terdiri atas Rencana Pelaksanaan Pembelajaran (RPP), Lembar Kegiatan Siswa (LKS), Buku Ajar Siswa, dan instrumen evaluasi. RPP, LKS, dan Buku Ajar Siswa yang sedang dikembangkan dengan menggunakan pembelajaran berbasis inkuiri terbimbing dengan menggunakan program simulasi PhET.

\section{B. Rancangan Penelitian}

Penelitian menggunakan metode 4-D (Four Model) yang dikembangkan oleh Thiagarajan, yaitu: (1) Tahap Pendefinisian, (2) Tahap Perancangan Perangkat, dan (3) Tahap Pengembangan Perangkat Pembelajaran (4) Penyebaran. Akan tetapi karena keterbatasan waktu dan dana peneliti hanya dilakukan sampai tahap pengembangan saja.

Peneliti melakukan observasi berupa pemberian tes uji miskonsepsi sebanyak dua kali yaitu sebelum pembelajaran dan sesudah penembelajaran.Penelitian ini dilakukan replikasi sebanyak tiga kali.Setelah itu dilaksanakan analisis secara statistik terhadap data yang diperolah. Diagram desain ini sebagai berikut:

Keterangan:

\section{$\mathrm{O}_{1} \mathrm{X} \mathrm{O}_{2}$}

$\mathrm{O}_{1}=$ Pretest

$\mathrm{X}=$ Perlakuan penerapan perangkat pembelajaran yang dikembangkan.

$\mathrm{O}_{2}=$ Posttest

\section{Metode Pengumpulan Data}

\section{Data Keterlaksanaan, Aktivitas dan Kendala}

Data keterlaksanaan pembelajaran, aktivitas siswa dan kendala-kendala selama KBM diperoleh melalui observasi yang dilakukan oleh dua orang pengamat yang melakukan pengamatan terhadap keterlaksanaan pembelajaran, aktivitas siswa dan kendala-kendala yang dihadapi selama kegiatan belajar mengajar berlangsung dengan menggunakan lembar pengamatan dan rubrik.

\section{Data Hasil Belajar}

Data hasil belajar diperoleh melalui instrumen tes uji miskonsepsi yang digunakan untuk mengukur dan merekam miskonsepsi siswa pada konsep listrik dinamis. Instrumen ini berbentuk tes pilihan ganda beralasan yang disertai taraf keyakinan siswa (CRI) dengan jumlah 30 soal yang dilakukan sebanyak dua kali, yaitu tes uji miskonsepsi awal (pretest) dan tes uji miskonsepsi akhir (postest).

\section{Data Respon Siswa}

Data respon siswa menggunakan angket untuk mengumpulkan informasi tentang respon siswa terhadap ketertarikan, kebaharuan, dan kemudahan dalam memahami BAS, LKS, penggunaan simulasi 
PhET dalam pembelajaran. Angket respon siswa diberikan pada siswa setelah seluruh KBM selesai.

\section{Teknik Analisis Data}

\section{Analisis hasil validasi Perangkat}

Analisa data dilakukan dengan deskriptif kualitatif yaitu dengan merata-rata skor masingmasing komponen.Hasil skor dicocokkan dengan kriteria seperti pada Tabel 3.2.

Tabel 3.2. Kategori skor validasi

\begin{tabular}{|c|c|l|}
\hline $1,00 \leq \mathrm{SV} \leq 1,69$ & $\begin{array}{l}\text { tidak } \\
\text { baik }\end{array}$ & $\begin{array}{l}\text { tidak layak, belum } \\
\text { dapat digunakan dan } \\
\text { masih memerlukan } \\
\text { konsultasi }\end{array}$ \\
\hline $1,70 \leq \mathrm{SV} \leq 2,59$ & $\begin{array}{l}\text { kuran } \\
\text { g baik }\end{array}$ & $\begin{array}{l}\text { kurang layak, dapat } \\
\text { digunakan dengan } \\
\text { revisi lebih besar }\end{array}$ \\
\hline $2,60 \leq \mathrm{SV} \leq 3,59$ & baik & $\begin{array}{l}\text { layak, dapat digunakan } \\
\text { dengan revisi kecil }\end{array}$ \\
\hline $3,60 \leq \mathrm{SV} \leq 4,00$ & $\begin{array}{l}\text { sanga } \\
\text { t baik }\end{array}$ & $\begin{array}{l}\text { layak, dapat digunakan } \\
\text { tanpa revisi }\end{array}$ \\
\hline
\end{tabular}

Keterangan: SV : Skor Validasi

\section{Analisis Keterbacaan Perangkat}

Teknik analisis tingkat keterbacaan BAS dan LKS dilakukan secara deskriptif kualitatif berdasarkan tingkat keterbacaan sebagai berikut:

$$
\text { Skor }=\frac{\text { Jumlah jawaban yang benar }}{\text { jumlah kata yang dilenyapkan }}
$$

Skor yang diperoleh selanjutnya diinterpretasikan berdasarkan tabel 3.3.

Tabel 3.3. Nilai Keterbacaan Perangkat

\begin{tabular}{|c|c|}
\hline Skor & Tingkat Keterbacaan \\
\hline Skor tes $>60 \%$ & Tinggi \\
\hline Skor tes $40 \%-60 \%$ & Sedang \\
\hline Skor tes $<40 \%$ & Rendah \\
\hline
\end{tabular}

(Sumber: Suryadi, 2007:198)

\section{Analisis Tingkat Kesukaran Perangkat}

Teknik analisis tingkat kesukaran BAS dan LKS dilakukan secara deskriptif kualitatif berdasarkan tingkat kesukaran sebagai berikut:

$$
\text { Skor }=\frac{\sum \text { kalimat yg sukar dipahami }}{\text { jumlah kalimat yang ada }} \times 100 \%
$$

Skor yang diperoleh selanjutnya diinterpretasikan berdasarkan tabel 3.4.

Tabel 3.4 Nilai Persentase Tingkat Kesukaran Perangkat

\begin{tabular}{|c|c|}
\hline Interval Skor & Kriteria \\
\hline$>81 \%$ & Sangat sukar dipahami \\
\hline $61 \%-80 \%$ & Sukar dipahami \\
\hline $41 \%-60 \%$ & Kurang dapat dipahami \\
\hline $21 \%-40 \%$ & Mudah dipahami \\
\hline$<20 \%$ & Sangat mudah dipahami \\
\hline & (Sumber: Hartati,2008:88)
\end{tabular}

\section{Analisis Keterlaksanaan Pembelajaran}

Hasil pengamatan keterlaksanaan pembelajaran dianalisis dengan cara menghitung hasil pengamatan (diamati oleh pengamat) berdasarkan nilai rata-rata tiap bagian untuk tiap-tiap RPP dan dikonversi menggunakan kriteria pada Tabel 3.5.

Tabel 3.5 Kriteria Keterlaksanaan Pembelajaran

\begin{tabular}{|c|c|}
\hline Selang & Kriteria \\
\hline $1,00-1,99$ & Tidak baik \\
\hline $2,00-2,99$ & Kurang baik \\
\hline $3,00-3,49$ & Cukup baik \\
\hline $3,50-4,00$ & Baik \\
\hline
\end{tabular}

(Suharsimi, 2001)

Reliabilitas instrumen ditentukan oleh penilaian dua pengamat dengan tingkat seluruh reliabilitas dihitung menggunakan rumus:

$$
\text { Percentageof agreement }=\left(1-\frac{A-B}{B+A}\right) \times 100 \%
$$

Keterangan:

$\mathrm{A}=$ frekuensi aspek aktivitas siswa yang teramati dengan frekuensi tinggi.

$\mathrm{B}=$ frekuensi aspek aktivitas siswa yang teramati dengan frekuensi rendah.

\section{Analisis Aktivitas Siswa}

Teknik analisis data pengamatan aktivitas siswa menggunakan deskriptif kuantitatif dan kualitatif untuk memberikan deskripsi aktivitas siswa selama kegiatan pembelajaran berbasis inkuiri terbimbing.Nilai dari keterlaksanaan pembelajaran yang dilakukan oleh dua pengamat yang sudah memahami lembar pengamatan benar, kemudian data diolah dengan menghitung menggunakan persentase aktivitas siswa menurut Arifin (2009) sebagai berikut: 


$$
P=\left(\frac{\sum K}{\sum N}\right) \times 100 \%
$$

(Arifin, 2009)

Keterangan:

$\mathrm{P} \quad$ : Persentase respon siswa

$\Sigma \mathrm{K} \quad$ : Jumlah skor respon siswa

$\Sigma \mathrm{N} \quad$ : Jumlah seluruh skor respon siswa

Pelaksanaan pengamatan masing-masing pengamat memberikan penilaian (4: baik; 3: cukup; 2: kurang baik; 1: tidak baik). Kriteria penilaian diperoleh dengan membandingkan rata-rata skala penilaian diberikan kedua pengamat dengan penilaian menurut Ratumanan dan Laurens (2001) sebagai berikut:

$1,00-1,49=$ tidak baik

$2,50-3,49=$ cukup baik

$1,50-2,49=$ kurang baik

$3,50-4,00=$ baik.

\section{Analisis Kendala saat Pembelajaran}

Temuankendala-kendala pembelajaran dan solusi alternatifnya untuk mengatasi kendala yang muncul dilakukan oleh pengamat dan peneliti baik sebelum maupun sesudah pembelajaran. Catatan kendala dianalisis melalui reduksi data sehingga bias ditarik kesimpulan.

\section{Analisis Data Miskonsepsi siswa}

Dalam penelitian ini, pengolahan data hasil pretest dan posttest menggunakan program SPSS $\mathrm{v}$ 23. Berdasarkan data hasil pretest dan posttest, kemudian dianalisis secara deskriptif kuantitatif yang terdiri dari:

a. Analisis data hasil pengetahuan

1) Ketuntasan Indikator

Ketuntasan indikator dihitung dengan menggunakan rumus:

$$
\mathrm{KI}=\frac{\sum \text { siswa yg mencapai indikator }}{\sum \text { siswa }} \times 100 \%
$$

Keterangan: $\mathrm{KI}=$ Ketuntasan Indikator

Suatu indikator dikatakan tuntas jika $\geq 70 \%$ siswa mencapai indikator.
2) Ketuntasan individual dan klasikal

Secara individu siswa telah tuntas belajarnya apabila rata-rata ketercapaian indikator yang mewakili tujuan pembelajaran memenuhi Kriteria Ketuntasan Minimal (KKM) Fisika di SMA Negeri 4 Surabaya yang ditetapkan sebesar 75 . Nilai tes hasil belajar siswa dianalisis dengan mengunakan rumus:

$$
\text { Nilai }=\frac{\text { skor yang diperoleh }}{\text { skor maksimal }} \times 100
$$

Ketuntasan hasil belajar secara klasikal dihitung dengan rumus:

$$
\mathrm{KK}=\frac{\sum \text { Siswa yg tuntas secara individu }}{\sum \text { Siswa }} \times 100 \%
$$

Keterangan: KK = Ketuntasan Klasikal.

Pembelajaran dikatakan mencapai ketuntasan klasikal jika memenuhi kriteria ketuntasan $\geq 85 \%$ (Saifuddin, 2010).

3) Penurunan miskonsepsi

Data pretest dan posttest hasil belajar dianalisis menggunakan skor gain ternormalisasi ( $N$-Gain Score) dengan rumus Hake (dalam Savinainem \& Scott, 2002) sebagai berikut:

$$
<g>=\frac{\text { Nilai posttest }- \text { Nilai Prettes }}{\text { Skor Maksimum }- \text { Nilai Prettest }}
$$

Data N-Gain yang diperoleh kemudian oleh Savinainen \& Scott (2002) dikategorikan ke dalam tiga tingkatan, yaitu:

a) pembelajaran dengan "gain tinggi", jika $<\mathrm{g}>\geq$ 0.7

b) pembelajaran dengan "gain sedang", jika 0.7 $><\mathrm{g}>\geq 0.3$

c) pembelajaran dengan "gain rendah", jika $<\mathrm{g}>0.3$

4) Analisis Statistik

Analisis statistik yang dilakukan untuk mengetahui perbedaan nilai rata-rata prettest dan posttest untuk tiap kelas dan untuk mengetahui perbedaan rata-rata $\mathrm{N}-\mathrm{Gain}$ pada seluruh kelas.

One Way ANOVA digunakan untuk mengetahui perbedaan rata-rata $\mathrm{N}$-Gain dari ketiga kelas 
implementasi dan replikasi yakni XI MIPA1, XI MIPA2, dan XI MIPA3

Hipotesis yang diuji meliputi:

$\mathrm{Ho}=$ rata-rata $\mathrm{N}$-Gain tiap kelas sama

$\mathrm{H}_{1}=$ minimal salah satu $\mu$ tidak sama

Pengambilan keputusan:

Ho ditolak jika Sig. $<0,05$

Ho diterima jika Sig $\geq 0,05$.

Uji t digunakan untuk mengetahui apakah ada pengaruh pembelajaran terhadap jumlah miskonsepsi tiap-tiap kelas dari satu variabel ( $N$-Gain). Jika distribusi data pretest dan posttest normal dan homogen maka digunakan uji t Independen t-test. Hipotesis yang diuji dalam (Independen t-test) meliputi:

$\mathrm{Ho}=$ tidak terdapat perbedaan antara rata-rata $\mathrm{N}$ Gain antar kelas.

$\mathrm{H} 1$ = terdapat perbedaan antara rata-rata $\mathrm{N}$-Gain antar kelas.

Dasar pengambilan keputusan:

Jika nilai signifikansi atau sig (2-tail)> 0,05 maka Ho diterima dan $\mathrm{H}_{1}$ ditolak

Jika nilai signifikansi atau sig (2-tail) $<0,05$ maka Ho ditolak dan $\mathrm{H}_{1}$ diterima.

\section{Analisis Respon Siswa}

Analisis data hasil respon yang diberikan siswa dianalisis dengan menggunakan analisis deskriptif kuantitatif berupa persentase. Persentase tiap respon dihitung dengan menggunakan rumus:

$$
\text { respon }=\frac{\text { jumlah aspek yg muncul }}{\text { jumlah siswa }} \times 100 \%
$$

Persentase respon siswa diadaptasi dari Riduwan (2010) dengan kriteria sebagai berikut:

$0 \%-20 \%=$ Tidak baik

$21 \%-40 \%=$ Kurang baik

$41 \%-60 \%=$ Cukup baik

$61 \%-80 \%=$ Baik

$81 \%-100 \%=$ Sangat baik

\section{HASIL DAN PEMBAHASAN}

A. Hasil Penelitian Kelayakan Perangkat Pembelajaran

\section{Hasil Validasi Pengembangan Perangkat}

a. RPP

Rencana Pelaksanaan Pembelajaran adalah suatu pedoman yang sistematis untuk memandu guru di dalam kelas dalam menyampaikan materi pelajaran. Hasil pengembangan perangkat pembelajaran yang berupa RPP yang telah divalidasi oleh pakar dapat dilihat dalam Tabel 4.1

\begin{tabular}{|c|c|c|c|c|c|c|}
\hline \multirow[t]{2}{*}{ No. } & \multirow[t]{2}{*}{ Aspek Penilaian } & \multicolumn{2}{|c|}{$\begin{array}{c}\text { Skor } \\
\text { Validasi }\end{array}$} & \multicolumn{2}{|c|}{ Rata-rata } & \multirow{2}{*}{$\begin{array}{c}\text { Reliabi } \\
\text { litas }\end{array}$} \\
\hline & & V1 & $\mathrm{V}_{2}$ & & & \\
\hline \multicolumn{7}{|c|}{ A. Tujuan Pembelajaran } \\
\hline 1 & Menuliskan Standar Kompe tensi & 4 & 4 & 4 & \multirow{4}{*}{$\begin{array}{c}3.7 \\
5\end{array}$} & 100 \\
\hline 2 & Menuliskan Kompetensi Dasar & 4 & 4 & 4 & & 100 \\
\hline 3 & Menuliskan Indikator & 4 & 4 & 4 & & 100 \\
\hline 4 & Kesesuaian Tujuan Pembelajatan dengan indikator & 3 & 3 & 3 & & 100 \\
\hline \multicolumn{7}{|c|}{ B. Kegiatan Pembelajaran } \\
\hline 1 & Guru memotivasi siswa dan memberi aspersepsi & 3 & 3 & 3 & \multirow{4}{*}{3.5} & 100 \\
\hline 2 & Guru menyampaikan tujuan pembelajan & 4 & 4 & 4 & & 100 \\
\hline 3 & $\begin{array}{l}\text { Model pembelajaran yang pilih sesuai dengan tujuan } \\
\text { pembelajaran }\end{array}$ & 3 & 3 & 3 & & 100 \\
\hline 4 & $\begin{array}{l}\text { Langkah-langkah model pembelajaran ditulis lengkap } \\
\text { dalam RPP }\end{array}$ & 4 & 4 & 4 & & 100 \\
\hline \multicolumn{7}{|c|}{ C. Pendukung Kegiatan Pembelajaran } \\
\hline 1 & $\begin{array}{l}\text { Penggunaan buku siswa, LKS, media simulasi PhET, } \\
\text { dan lembar penilaian diskenariokan dalam RPP }\end{array}$ & 3 & 3 & 3 & \multirow[t]{2}{*}{3,5} & 100 \\
\hline 2 & LKS menunjang ketercapaian tujuan pembelajaran & 4 & 4 & 4 & & 100 \\
\hline \multicolumn{7}{|c|}{ D. Waktu } \\
\hline 1 & $\begin{array}{l}\text { Pembagian waktu setiap kegiatan fase dinyatakan } \\
\text { dengan jelas }\end{array}$ & 4 & 4 & 4 & \multirow[t]{2}{*}{3.5} & 100 \\
\hline 2 & Kesesuaian waktu setiap fase/ kegiatan & 3 & 3 & 3 & & 100 \\
\hline \multicolumn{7}{|c|}{ E. Metode Sajian } \\
\hline 1 & $\begin{array}{l}\text { Sebelum menyajikan konsep baru, sajian dikaitkan } \\
\text { dengan konsep yang telah dimiliki siswa }\end{array}$ & 4 & 3 & 3.5 & \multirow{3}{*}{3.7} & 86 \\
\hline 2 & Memberikan kesempatan bertanya pada siswa & 4 & 3 & 3.5 & & 86 \\
\hline 3 & Guru mengecek pemahaman siswa & 4 & 4 & 4 & & 100 \\
\hline \multicolumn{7}{|c|}{ F. Bahasa } \\
\hline 1. & $\begin{array}{l}\text { Menggunakan kaidah bahasa Indonesia yang baik dan } \\
\text { benar }\end{array}$ & 3 & 3 & 3 & \multirow[t]{2}{*}{3,25} & 86 \\
\hline 2. & ke tepatan struktur ka limat & 4 & 3 & 3.5 & & 86 \\
\hline \multicolumn{5}{|c|}{ Rata-rata } & 3.53 & $97 \%$ \\
\hline
\end{tabular}

\section{b. Buku Ajar Siswa (BAS)}

Buku siswa merupakan perangkat yang berfungsi sebagai panduan belajar oleh siswa selama proses belajar mengajar. Buku ajar yang dikembangkan peneliti sesuai dengan materi yang diambil yaitu listrik dinamis. Berdasaarkan table 4.3 disimpulkan bahwa nilai rata-rata skor total buku ajar siswa adalah 3,1dengan kategori baik. (Ratumanan dan Laurens, 2006). Analisis data hasil validasi buku ajar siswa secara lengkap dapat dilihat pada Tabel 4.3 
Tabel 4.3 Hasil Analisis Validasi BAS

\begin{tabular}{|c|c|c|c|c|c|c|}
\hline No & $\begin{array}{l}\text { Aspek Penilaian } \\
\text { aponen Kelayakan Iri }\end{array}$ & \begin{tabular}{l}
\multicolumn{2}{|c|}{ Nilai } \\
V1
\end{tabular} & & \multicolumn{2}{|c|}{ Rata-rata } & $\begin{array}{c}\text { Reliabilitas } \\
\%\end{array}$ \\
\hline \multicolumn{7}{|c|}{ I. Komponen Kelayakan Isi } \\
\hline \multicolumn{7}{|c|}{ A. Cakupan Materi } \\
\hline 1 & \begin{tabular}{|l|} 
Keluasan materi \\
\end{tabular} & 3 & 3.0 & 3.0 & \multirow{2}{*}{3.0} & 100 \\
\hline 2 & Kodalaman materi & 3 & 3.0 & 3.0 & & 100 \\
\hline \multicolumn{7}{|c|}{ B. Akw asi Materi } \\
\hline 1 & Akuasi fakta & 4 & 3 & 3.5 & \multirow{5}{*}{3,4} & 86 \\
\hline 2 & Alwasi konse? & 3 & 3 & 3,0 & & 100 \\
\hline 3 & Alwassi prinsipholisum & 4 & 3 & 3,5 & & 86 \\
\hline 4 & Alurasi prosudur metode & 4 & 3 & 3,5 & & 86 \\
\hline 5 & Alumas Bori & 4 & 3 & 3,5 & & 86 \\
\hline \multicolumn{7}{|c|}{ C. Kemutakhiran } \\
\hline 1 & \begin{tabular}{|l|l|}
$\begin{array}{l}\text { Kesesuaian dengan pekembangan ilmu den } \\
\text { elknolog }\end{array}$ \\
\end{tabular} & 3 & 3 & 3,0 & \multirow{3}{*}{3,2} & 100 \\
\hline 2 & $\begin{array}{l}\text { Keterkiniankelemasaan fitur (contob-contoh) } \\
\end{array}$ & 3 & 3 & 3,0 & & 100 \\
\hline 3 & $\begin{array}{l}\text { Satuan yang dignakan adalah satuan Sistem } \\
\text { Intemasional(SI) }\end{array}$ & 4 & 3 & 3,5 & & 86 \\
\hline \multicolumn{7}{|c|}{ D. Mengandung Wawasan Produktivitas } \\
\hline 1 & Manumbuhlan uemangut kwiavuhun & 3 & 3 & 3,0 & & 100 \\
\hline 2 & Menumbuhlan etos kejas & 4 & 3 & 3,5 & 3.2 & 86 \\
\hline 3 & $\begin{array}{l}\text { Manumbuhlan semangat inowas, lseativitas, dan } \\
\text { berpikis krits }\end{array}$ & 3 & 3 & 3,0 & 3,2 & 100 \\
\hline E.M & rangsang Keingintauhan & & & & & \\
\hline 1 & Menumbuhlan rasa ingin tav & 4 & 3 & 3,5 & 33 & 86 \\
\hline 2 & Member tantangan untutk belajar lebih gat & 3 & 3 & 3,0 & 9,3 & 100 \\
\hline Rerat: & askor komponen dan kiaguakan iti & & & & 3,2 & \\
\hline II. $\mathrm{k}$ & Omponen Kebahasaan & & & & & \\
\hline A. & Sesuai dengan Perkem banganPeserta Didik & & & & & \\
\hline 1 & $\begin{array}{l}\text { Kesesudian dengan tingkat perkembangan beppikir } \\
\text { siswa }\end{array}$ & 3 & 3,0 & $\overline{0}$ & & 100 \\
\hline 2 & $\begin{array}{l}\text { Kevesuai dengan tinglat perlambongan sosial- } \\
\text { emosional siswa }\end{array}$ & 3 & 3,0 & 3,0 & & 100 \\
\hline B. Ko & mumikatif & & & & & \\
\hline 1 & \begin{tabular}{|l|l|}
$\begin{array}{l}\text { Keterpahaman sistra terhadap pean yang } \\
\text { disampaikan }\end{array}$ & \\
\end{tabular} & 3 & 3,0 & 3,0 & & 100 \\
\hline 2 & \begin{tabular}{|l|l|} 
Kesesua ian ilustrasi dengan subsanssi peasn \\
\end{tabular} & 3 & 3,0 & & & 100 \\
\hline C.Lu & & & & & & \\
\hline 1 & \begin{tabular}{|l|l} 
Ketepatan strustux kalimat \\
\end{tabular} & 3 & 3,0 & 0 & & 100 \\
\hline 2 & Kebakuan istilah & 3 & 3,0 & 3,0 & & 100 \\
\hline D. Ke & herensi dan Keruntutan A hur Piker & & & & & \\
\hline 1 & $\begin{array}{l}\text { Keteravtan anter bab, antan bab dan wobab, antre } \\
\text { subbab dalam bab, antrastenia dalam subbab }\end{array}$ & 3 & 3 & 3,0 & & 100 \\
\hline 2 & Keteravtan antrialimat dalam sarv alenia & 3 & 3 & 3,0 & 3,0 & 100 \\
\hline 3 & $\begin{array}{l}\text { Keutuhan malsa dalam bab, dalam subbab, dan } \\
\text { makna dalam anv alenia }\end{array}$ & 3 & 3 & 3,0 & & 100 \\
\hline$\overline{E . K e}$ & sesuaian de ngan Kaidah Bahasa Indonesia Yang Bena & & & & & \\
\hline 1 & \begin{tabular}{|l|} 
Kerepatan tatabahasa \\
\end{tabular} & 3 & 3 & 3,0 & & 100 \\
\hline 2 & Ketepatan ejajan & 3 & 3 & 3,0 & 2,0 & 100 \\
\hline F. Pe & gggmaan Istiah dan SimbolLam bang & & & & & \\
\hline 1 & Konsistensi pengquanan itrilah & 3 & 3 & 3,0 & & 100 \\
\hline 2 & Konsistensi pengevanan symbollambang & 3 & 3 & 3,0 & 3,0 & 100 \\
\hline & Rerata skor komponen ke dahazaan & & & 3.0 & & \\
\hline III. K & omponen peryajan & & & & & \\
\hline A. Te & knik pervajian & & & & & \\
\hline 1 & Konsistensi sistematika sjän da lam bab & 3 & 3 & 3,0 & & 100 \\
\hline 2 & Kelogisn penyajan & 4 & 3 & 3,5 & & 86 \\
\hline 3 & Ketenoutan konsep & 4 & 3 & 3,5 & & 86 \\
\hline 4 & $\begin{array}{l}\text { Hubungan antar fakta, antr konsep dan anar } \\
\text { prinsip, serta aras eori }\end{array}$ & 3 & 3 & 3,0 & & 100 \\
\hline 5 & $\begin{array}{l}\text { Kestimbangan antar bab dan ke seinbangan } \\
\text { substansia anar stobab dalam bab }\end{array}$ & 3 & 3 & 3,0 & 3,1 & 100 \\
\hline 6 & 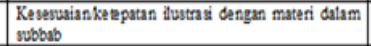 & 3 & 3 & 3,0 & & 100 \\
\hline 7 & 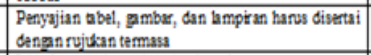 & 3 & 3 & 3,0 & & 100 \\
\hline 8 & Identitas tabel ganbas den lampiran & 3 & 3 & 3,0 & & 100 \\
\hline B. Pe & adukung penyajian materi & & & & & \\
\hline 1 & Pengantar & 3 & 3 & 3,0 & & 100 \\
\hline 2 & Lampiran: Ringkasan & 3 & 3 & 3,0 & & 100 \\
\hline 3 & Lampiran: Glowrivm & 3 & 3 & 3,0 & 3,0 & 100 \\
\hline 4 & Lampiran: Indeks & 3 & 3 & 3,0 & & 100 \\
\hline 5 & Lampiran: Dafar putaka & 3 & 3 & 3,0 & & 100 \\
\hline C.Pe & ayajian pembelajar an & & & & & \\
\hline 1 & Berpuat pada siswa & 3 & 3 & 3,0 & & 100 \\
\hline 2 & Ketelibatan siswa & 3 & 3 & 3,0 & & 100 \\
\hline 3 & 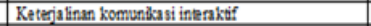 & 3 & 3 & 3,0 & 3,0 & 100 \\
\hline 4 & Kesesuaisa dergan laniteristlk mata pelajarn & 3 & 3 & 3,0 & & 100 \\
\hline 5 & Kemampuan merangang kedalem berpikir siswa & 3 & 3 & 3,0 & & 100 \\
\hline & $\begin{array}{l}\text { thor homponen pe ryajian } \\
\text { an: }\end{array}$ & & & 3,0 & & $93 \%$ \\
\hline
\end{tabular}

\section{c. Lembar Kegiatan Siswa (LKS)}

Lembar kegiatan siswa yang dikembangkan adalah LKS yang mengacu pada pembelajaran berbasis inkuiri terbimbing dengan menggunakan program simulasi PhET. Hasil validasi LKS disajikan dalam Tabel 4.5
Tabel 4.5 Hasil Analisis Validasi LKS

\begin{tabular}{|c|c|c|c|c|c|c|}
\hline \multirow[b]{2}{*}{ No. } & \multirow[b]{2}{*}{ Aspek Yang Dinilai } & \multicolumn{2}{|c|}{ Nilai } & \multirow{2}{*}{\multicolumn{2}{|c|}{$\begin{array}{l}\text { Rata- } \\
\text { rata }\end{array}$}} & \multirow{2}{*}{$\begin{array}{l}\text { Relia } \\
\text { bilita } \\
\%\end{array}$} \\
\hline & & V1 & V2 & & & \\
\hline \multicolumn{7}{|c|}{ A. Aspek petuniuk } \\
\hline 1 & Petunjuk dinyatakan dengan jelas & 4 & 4 & 4,0 & \multirow[b]{3}{*}{4,0} & 100 \\
\hline 2 & Mencantumkan tyjuan pembelajaran & 4 & 4 & 4,0 & & 100 \\
\hline 3 & $\begin{array}{l}\text { Materi LKS sesuai dengan tujuan pembelajaran } \\
\text { di LKS dan RPP }\end{array}$ & 4 & 4 & 4,0 & & 100 \\
\hline \multicolumn{7}{|c|}{ B. Kelayakan Isi } \\
\hline 1 & Keluasan materi & 3 & 4 & 3,5 & \multirow{11}{*}{3,9} & 86 \\
\hline 2 & Kedalaman materi & 3 & 3 & 3,0 & & 100 \\
\hline 3 & Akurasi fakta & 4 & 4 & 4,0 & & 100 \\
\hline 4 & Kebenaran konsep & 4 & 4 & 4,0 & & 100 \\
\hline 5 & Kebenaran prinsip dan hukum & 4 & 4 & 4,0 & & 100 \\
\hline 6 & $\begin{array}{l}\begin{array}{l}\text { Kesesuaian dengan perkembangan ilmu } \\
\text { pengetahuan }\end{array}\end{array}$ & 4 & 4 & 4,0 & & 100 \\
\hline 7 & Akurasi teoni & 4 & 4 & 4,0 & & 100 \\
\hline 8 & Akurasi prosedur atau metode & 4 & 4 & 4,0 & & 100 \\
\hline 9 & Menumbuhkan kreativitas & 4 & 4 & 4,0 & & 100 \\
\hline 10 & Menumbuhkan rasa ingin tahu & 4 & 4 & 4,0 & & 100 \\
\hline 11 & $\begin{array}{l}\text { Mendorong untuk mencari informasi lebih } \\
\text { lanjut }\end{array}$ & 4 & 4 & 4,0 & & 100 \\
\hline \multicolumn{7}{|c|}{ C. Prosedur } \\
\hline 1 & Urutan keja & 3 & 3 & 3,0 & \multirow[b]{2}{*}{3,2} & 100 \\
\hline 2 & Keterbacaan bahasa dari prosedur & 4 & 3 & 3,5 & & 86 \\
\hline \multicolumn{7}{|c|}{ D. Pertanyaan } \\
\hline 1 & \begin{tabular}{|l} 
Kesesuaian pertanyaan dengan tujuan \\
pembelajaran di LKS dan RPP
\end{tabular} & 4 & 3 & 3,5 & \multirow{3}{*}{3,5} & 86 \\
\hline 2 & Pertanyaan mendukung konsep & 4 & 3 & 3,5 & & 86 \\
\hline 3 & Keterbacaan bahasa dari pertanyaan & 4 & 3 & 3,5 & & 86 \\
\hline \multicolumn{4}{|c|}{ Rata-rata } & & 3,6 & $96 \%$ \\
\hline
\end{tabular}

Berdasarkan tabel 4.5 diperoleh hasil validasi LKS yang diperoleh dari validator pertama dan kedua yang meliputi aspek petunjuk, kelayakan isi, prosedur dan pertanyaan mempunyai nilai antara 3 sampai 4. Rata-rata skor validasinya 3,6 dengan kategori sangat baik dengan realibilitas $96 \%$.

\section{d. Tes Uji Miskonsepsi}

Hasil analisis data hasil penilaian terhadap pengembangan perangkat tes uji miskonsepsi oleh ahli secara rata-rata 1,69 dan dinyatakan cukup baik (Ratumanan dan Laurens, 2006).

\section{e. Tingkat Keterbacaan BASdan LKS}

Tabel 4.9 menunjukkan hasil uji keterbacaan BAS yang dikembangkan oleh peneliti rata-rata skor sebesar 59,8 dengan kategori sedang, dan tingkat keterbacaan LKS yang dikembangkan oleh peneliti rata-rata skor sebesar 71,3 dengan kategori tinggi.

\section{f. Tingkat Kesulitan BAS dan LKS}

Tingkat kesulitan buku siswa dan LKS dievaluasi dalam beberapa tahap. Tiap tahapan 
terlihat pada setiap pertemuan yang dilaksanakan dalam materi listrik dinamis dalam tiga kali pertemuan. Dalam setiap pertemuan, guru menyarankan siswa untuk menggarisbawahi kalimat yang tidak dimengerti. Guru mengambil sampel 10 siswa untuk diambil datanya.Hasil analisis persentase tingkat kesulitan buku siswa dan LKS menunjukkan rata-rata tingkat kesulitan buku ajar siswa 32,5\% dengan kategori mudah dipahami, dan rata-rata tingkat kesulitan LKS 34,3\% dengan kategori mudah dipahami.

\section{Kepraktisan Perangkat Pembelajaran \\ a. Keterlaksanaan RPP}

Hasil pengamatan keterlaksanaan RPP pada kelas XI.MIPA1, XI.MIPA2, dan XI.MIPA3 yang dilakukan oleh dua pengamat ditunjukkan pada tabel 4.11 .
Tabel 4.11 Hasil pengamatan keterlaksanaan RPP untuk masing-masing kelas.

\begin{tabular}{|c|c|c|c|c|c|c|c|}
\hline \multirow{3}{*}{ No } & \multirow{3}{*}{ Aspek yang diamati } & \multicolumn{6}{|c|}{ Rata-rata keterlaks anaan RPP } \\
\hline & & \multicolumn{2}{|c|}{ XIMIPA1 } & \multicolumn{2}{|c|}{ XIMIPA2 } & \multicolumn{2}{|c|}{ XIMIPA3 } \\
\hline & & & K & $x$ & $\mathrm{k}$ & & $\mathrm{K}$ \\
\hline \multicolumn{8}{|c|}{ 1. Pelaksanaan } \\
\hline \multirow{5}{*}{\begin{tabular}{l|l} 
A & \\
&
\end{tabular}} & \multicolumn{7}{|l|}{ Pendahuluan } \\
\hline & \multicolumn{7}{|l|}{ 1. Menyampaiakan tujuan/mempersiapkan siswa } \\
\hline & a. Memotivasi sisw a & 4.0 & $B$ & 3.8 & $B$ & 4.0 & $B$ \\
\hline & $\begin{array}{l}\text { b. Mendemonstrasikan pengetahu an atav } \\
\text { keterampilan }\end{array}$ & 3.8 & B & 3.5 & B & 3.7 & B \\
\hline & c. Menyampaikan tujuan pembelajaran & 4.0 & B & 3.5 & B & 3.7 & $B$ \\
\hline \multicolumn{8}{|c|}{ B. Kegiatan Inti } \\
\hline & 1. Meng orrientasikan sisw a pad a masalah & & & & & & \\
\hline & a. Memb agi sisw a dalam beberapa kelompok & 4.0 & B & 33 & $C B$ & 33 & $C B$ \\
\hline & b. Memb agi LKS kepada tiap kelompok & 4.0 & B & 3.7 & B & 4.0 & B \\
\hline & $\begin{array}{l}\text { c. Menj elas lan mod el pemb elajaran yang akan } \\
\text { digunakan serta lang lah-langkahnya }\end{array}$ & 3.3 & $\mathrm{CB}$ & 33 & $\mathrm{CB}$ & 3.3 & $\mathrm{CB}$ \\
\hline & $\begin{array}{l}\text { d. Menampillan suatu masalah yang akan } \\
\text { diselidiki }\end{array}$ & 3.0 & $\mathrm{CB}$ & 3.0 & $C B$ & 33 & $\mathrm{CB}$ \\
\hline & \multicolumn{7}{|l|}{ 2. Merumuskan hip otexis } \\
\hline & $\begin{array}{l}\text { a. Membimbing sisw a untuk merumus lan hipotesis } \\
\text { sesu ai deng an rumusan masalah yang ad a }\end{array}$ & 4.0 & B & 3.7 & B & 4.0 & B \\
\hline & 3. Melakukan kegiatan p enemuan & & & & & & \\
\hline & $\begin{array}{l}\text { a. Membimbing sisw a untuk merencanakan } \\
\text { percobaan }\end{array}$ & 3.8 & B & 3.8 & B & 3.8 & $\mathrm{~B}$ \\
\hline & $\begin{array}{l}\text { b. Membimbing sisw a melalsanalan kegiatan sesuai } \\
\text { dengan LKS }\end{array}$ & 3.7 & B & 3.7 & B & 3.5 & B \\
\hline & c. Membimbing sisw a menganalisis data & 3.7 & B & 3.7 & $B$ & 3.7 & B \\
\hline & $\begin{array}{l}\text { d. Membimbing siswa untuk membuat simpulan dari } \\
\text { analisa data }\end{array}$ & 3.3 & $\mathrm{CB}$ & 32 & $C B$ & 33 & $\mathrm{CB}$ \\
\hline & $\begin{array}{l}\text { e. Memandu siswa untuk menj aw ab pertanyaan dalam } \\
\text { LKS dengan mengacu pada Buku Siswa }\end{array}$ & 3.2 & $C B$ & 32 & $C B$ & 3.2 & CB \\
\hline & \multicolumn{7}{|l|}{ 4. Mempresentasikan hasil kegiatan penemuan } \\
\hline & $\begin{array}{l}\text { a. Membimbing siswa untuk presentasi hasil } \\
\text { penemvan mow alkili kelompok }\end{array}$ & 3.3 & $C B$ & 3.3 & $C B$ & 3.3 & CB \\
\hline & $\begin{array}{l}\text { b. Membimbing siswa memberilan tanggapan kepada } \\
\text { belompok lain }\end{array}$ & 3.5 & B & 3.5 & B & 3.5 & B \\
\hline & $\begin{array}{l}\text { c. Membimbing siswa untuk merumus kan simpulan } \\
\text { dan merangkum materi pembelajaran }\end{array}$ & 3.5 & B & 3.3 & $C B$ & 3.5 & B \\
\hline \multirow[t]{4}{*}{ C. } & \multicolumn{7}{|l|}{ Kegiatan Akhir } \\
\hline & 1. Meng evaluasi kegiatan penemuan & & & & & & \\
\hline & $\begin{array}{l}\text { a. Membimbing sisw a untuk melakulan reflelsi atav } \\
\text { evalu asi terhadap peng amatan, penguluran, } \\
\text { penyelidikan, dan proses proses yang digunakan. }\end{array}$ & 3.2 & $C B$ & 3.0 & $C B$ & 32 & $C B$ \\
\hline & b. Memberikan evaluasi & 3.7 & B & 3.3 & $C B$ & 3.3 & $C B$ \\
\hline \multicolumn{8}{|c|}{ Pengelolaan Waktu } \\
\hline & a. Waltu sesuai alokasi & 3.0 & $\mathrm{CB}$ & 3.0 & $\mathrm{CB}$ & 3.0 & $C B$ \\
\hline & b. KBM sesuai skenario & 3.2 & $\mathrm{CB}$ & 3.2 & $\mathrm{CB}$ & 3.2 & $C B$ \\
\hline 3 & Respon/Antusiasme & & & & & & \\
\hline & a. Antusizsme siswa & 3.7 & $\mathrm{~B}$ & 3.5 & $\mathrm{~B}$ & 3.8 & $\mathrm{~B}$ \\
\hline & b. Antusiasme guru & 4.0 & B & 4.0 & B & 3.7 & $\mathrm{~B}$ \\
\hline Rata & arata & & & 3,4 & & & $B$ \\
\hline
\end{tabular}

Keterangan: $\bar{X}=$ nilai rata-rata: $\mathrm{K}=$ kategori $: \mathrm{B}=$ baik: $\mathrm{CB}=$ culoup baik

Berdasarkan tabel 4.11 semua tahap-tahap kegiatan yang ada di dalam RPP pada Kelas XI.MIPA1, XI.MIPA2 dan XI.MIPA3 terlaksana dan rata-rata keseluruhan skor keterlaksanaan RPP adalah 3,4 dengan kategori cukup baik.

\section{b. Aktivitas Siswa}

Persentase hasil pengamatan aktivitas siswa untuk kelas XI.MIPA1, XI.MIPA2, dan XI.MIPA3.Berdasarkan hasil analisis menunjukkan bahwa rata-rata aktivitas siswa yang dominan dilakukan oleh siswa adalah melakukan percobaan dengan simulasi PhET dan menyimpulkan hasil percobaan.

\section{c. Kendala Dalam KBM}

Kendala-kendala yang terjadi selama kegiatan pembelajaran diamati oleh dua orang pengamat, yaitu 
siswa belum terbiasa menggunakan program simulasi $\mathrm{PhET}$ dan menentukan variable-variabel pada percobaan.

\section{Keefektifan Perangkat pembelajaran}

a. Hasil Tes Uji Miskonsepsi

Hasil analisis tes uji miskonsepsi menujukkan rata-rata penurunan miskonsepsi siswa untuk kelas XI.MIPA1 sebesar 28,84 dengan penuruan miskonsepsi yang diperoleh dari perhitungan $\mathrm{N}$-gain hasil tes miskonsepsi rata-rata sebesar 0,72 ; rata-rata penurunan miskonsepsi siswa untuk kelas XI.MIPA2 sebesar 26,39 dengan penuruan miskonsepsi yang diperoleh dari perhitungan $\mathrm{N}$-gain hasil tes miskonsepsi rata-rata sebesar 0,77 dan rata-rata penurunan miskonsepsi siswa untuk kelas XI.MIPA3 sebesar 37,27 dengan penuruan miskonsepsi diperoleh dari perhitungan $\mathrm{N}$-gain hasil tes miskonsepsi rata-rata sebesar 0,77.

\section{1) Uji statistik}

Berdasarkan hasil output uji normalitas dengan menggunakan uji Kolmogorov-Smirnov pada Tabel 4.16 nilai signifikansi data nilai $N$-Gain untuk masing-masing kelas menunjukkan lebih besar dari 0,05 . Berdasarkan kriteria pengambilan keputusan maka Ho diterima. Hal ini berarti bahwa sampel dari ketiga kelas berasal dari populasi yang berdistribusi normal

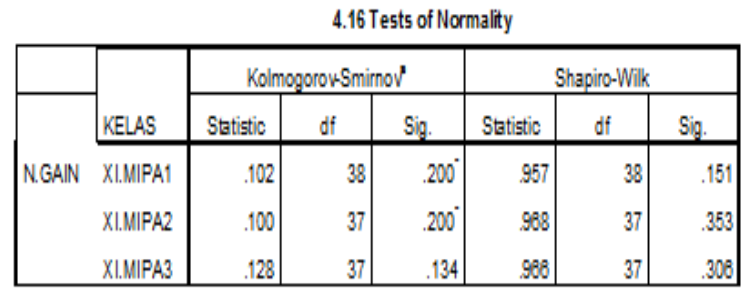

Berdasarkan hasil output uji homogenitas dengan menggunakan uji Levenemenunjukkan nilai signifikansinya adalah 0,125 . Karena nilai signifikansi lebih besar dari 0,05 maka berdasarkan kriteria pengambilan keputusan dapat disimpulkan bahwa tidak terdapat perbedaan varians antara ketiga kelas atau dengan kata lain varians antara ketiga kelas adalah sama.
4.17 Test of Homogeneity of Variances N.GAIN

\begin{tabular}{|r|r|r|r|}
\hline Levene Statistic & df1 & df2 & Sig. \\
\hline 2.124 & 2 & 109 & .125 \\
\hline
\end{tabular}

Hasil Uji Statistik dengan One Way ANOVA N.GAIN

\begin{tabular}{|l|r|r|r|r|r|}
\hline & $\begin{array}{r}\text { Sum of } \\
\text { Squares }\end{array}$ & df & $\begin{array}{r}\text { Mean } \\
\text { Square }\end{array}$ & F & Sig. \\
\hline $\begin{array}{l}\text { Betwee } \\
\mathrm{n}\end{array}$ & .063 & 2 & .031 & 2.331 & .102 \\
$\begin{array}{l}\text { Groups } \\
\text { Within } \\
\text { Groups } \\
\text { Total }\end{array}$ & 1.471 & 109 & .013 & & \\
\hline
\end{tabular}

Berdasarkan hasil outputuji statistik dengan One Way ANOVA sebagaimana disajikan pada tabel 4.18 menunjukkan bahwa harga $\mathrm{F}$ untuk between Groups besarnya 2,331 dengan nilai signifikansi $\mathrm{N}$-Gain 0,102. Hasil analisis menunjukkan bahwa nilai signifikansi 0,102 lebih besar daripada 0,05, dengan demikian Ho diterima dimana rata-rata $\mathrm{N}$-Gain penurunan miskonsesi siswa pada masing-masing kelas identik atau sama. Jadi kesimpulannya tidak ada perbedaan yang signifikan penurunan miskonsepsi dari ketiga kelas setelah siswa diberi pembelajaran berbasis inkuiri dengan menggunakan program simulasi PhETatau dengan kata lain dapat dikatakan bahwa perangkat pembelajaran yang digunakan untuk tiap-tiap kelas memiliki pengaruh yang relative sama (konsisten) untuk tiap-tiap kelas.

Berdasarkan Tabel 4.19 hasil outputuji statistik dengan uji t menunjukkan nilai signifikansi 0,061 . Nilai signifikansi lebih besar dari 0,05 , sehingga untuk pengambilan keputusan adalah menerima Ho dan menolak H1: $\mu 1<\mu 2$ atau H1: $\mu 1 \leq 0$. Sehingga dapat disimpulkan bahwa $\mathrm{N}$-Gain penurunan miskonsesi siswa dialami pada masing-masing kelas atau dengan kata lain penurunan miskonsepsi dialami setiap siswa setelah siswa mengikuti pembelajaran dengan menggunakan program simulasi PhET. 


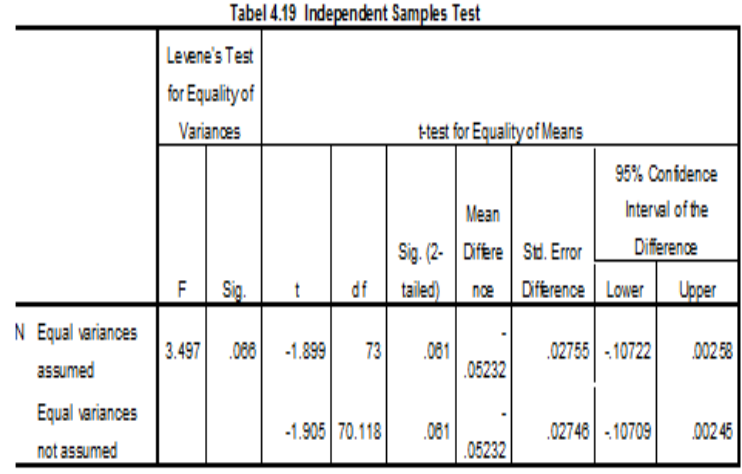

\section{Respon Siswa}

Berdasarkan hasil analisis Tabel 4.24 menunjukkan bahwa skor rata-rata respon siswa terbesar pada komponen merasa baru dalam penggunaan program simulasi $\mathrm{PhET}$ dalam pembelajaran sebesar $100 \%$.

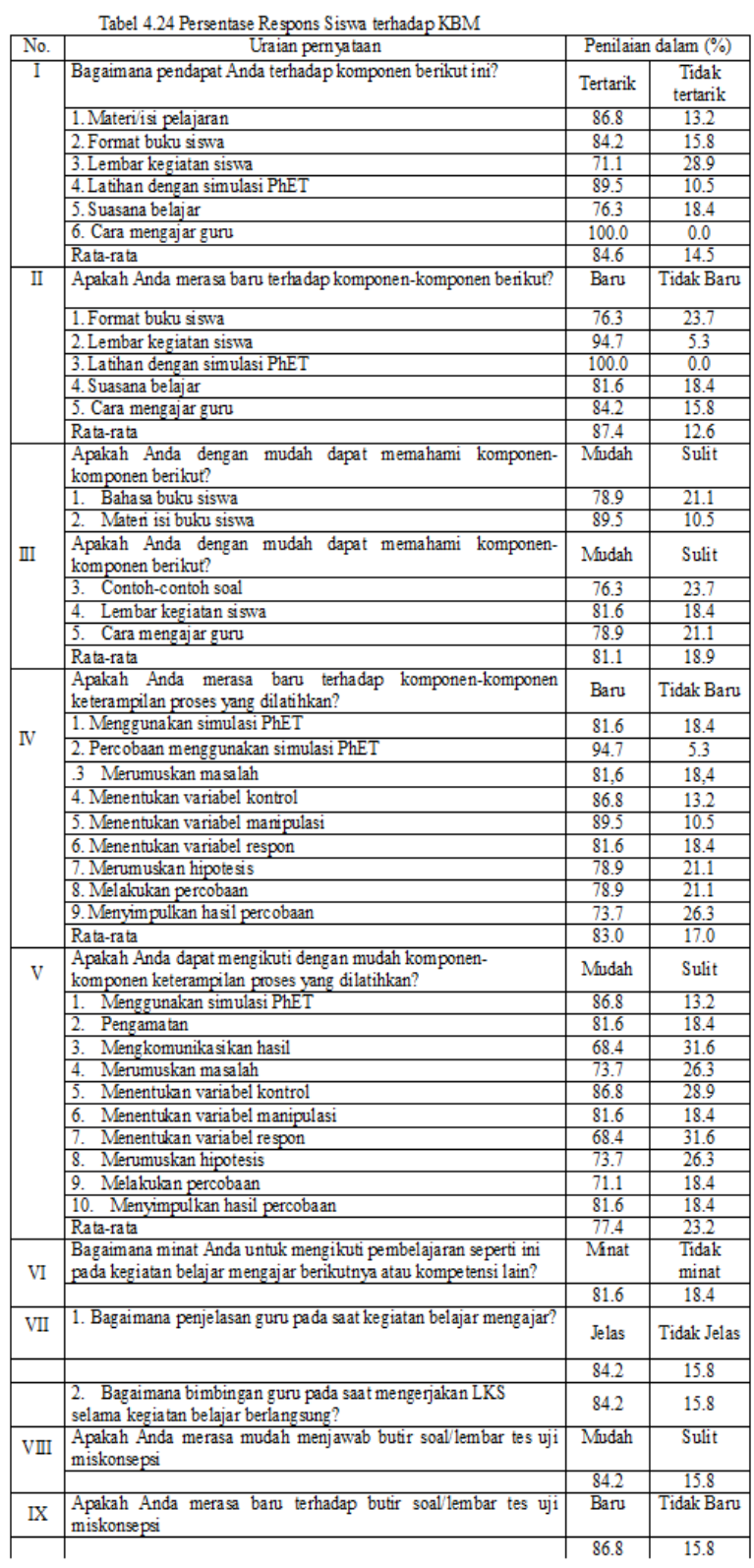

\section{PENUTUP}

\section{Kevalidan Perangkat}

Berdasarkan hasil analisis kevalidan perangkat pembelajaran, di atas maka perangkat dikatakan valid karena telah memenuhi kriteria:

a. Validitas konseptual perangkat pembelajaran bernilai baik antara $3,0 \leq \mathrm{SV} \leq 3.53$. melebihi target yang telah ditetapkan sebesar $2,6 \leq \mathrm{SV} \leq 3,5$.

b. Tingkat keterbacaan perangkat BAS dan LKS bernilai antara $59,8 \%$ sampai $71,3 \%$, melebihi 
target yang telah ditetapkan sebesar $40 \%$ sampai $60 \%$.

c. Tingkat kesulitan BAS dan LKS bernilai 34,3\% sampai $32,5 \%$ dengan kategori mudah dipahami lebih kecil dari target yang telah ditetapkan sebesar $40 \%$.

\section{Kepraktisan Perangkat Pembelajaran}

Berdasarkan hasil analisis kepraktisan perangkat pembelajaran, di atas maka perangkat dikatakan praktis karena telah memenuhi kriteria:

a. Keterlaksanaan RPPskor rata-rata sebesar 3,4 dengan kategori cukup baik melebihi target yang telah ditetapkan sebesar 3,00 dengan kategori cukup baik

b. Aktivitas siswa berpusat pada siswa dengan ditunjukkannya aktivitas terbanyak pada kegiatan melakukan latihan dengan menggunakan program simulasi PhET atau penyelidikan.

c. Kendala yang ditemukan selama proses kegiatan pembelajaran dapat diatasi.

\section{Keefektifan Perangkat Pembelajaran}

Berdasarkan hasil analisis keefektifan perangkat pembelajaran, di atas maka perangkat dikatakan efektif karena telah memenuhi kriteria:

a. Miskonsepsi siswa menurun dengan skor peningkatan (N-Gain) dengan nilai signifikansinya 0,73 melebihi target yang telah ditetapkan sebesar 0,3.

b. Respon siswa baik dengan adanya perhatian, relevansi, percaya diri, dan kepuasan siswa bernilai $68,7 \%$ - 88,3\% melebihi target yang telah ditetapkan sebesar $41 \%-60 \%$.

Berdasarkan temuan-temuan dan pemenuhan kriteria kevalidan, kriteria kepraktisan dan kriteria keefektifan, maka perangkat pembelajaran yang dikembangkan layak digunakan dalam kegiatan pembelajaran.

\section{DAFTAR PUSTAKA}

Abdullah, S. (2008).The Effect of Inquiry-Based Computer Simulation with Cooperative Learning on Scientific Thinking and Conceptual Understanding of Gas Laws. Eurasia Journal of Mathematic, Science \& Technology (online) Tersedia: http://www.ejmste.com/. Diakses pada tanggal 20 November 2013.

Arifin, Z 2010.EvaluasiPembelajaran Prinsip, teknik dan Prosedur. Bandung: Remaja Rosadakarya.

Arikunto, S. (2012).Dasar-dasar evaluasi pendidikan Edisi 2.Jakarta: Bumi Aksara

Bilgin, I. 2009. The effects of guided inquiry instruction incorporating a cooperative learning approach on university students achievement of acid and bases concepts and attitude toward guided inquiry instruction Scientific Research and Essay Academic journal. [online] tersedia http://www.academicjournals.org/sre/pdf/pd f2009/Oct/Bilgin.pdf

BSNP, 2006.Standar isi, Standar Kompetensi dan kompetensi Dasar Penggunaan aplikasi multimedia pembelajaran topologi jaringan komputer berbasis SMA/MA. Jakarta: BNSP

Cahaya, I. B. macromedia flash untuk meningkatkan hasil belajar mata pelajaran tik siswa kelas XI SMAN I Godean. Universitas Negeri Yogyakarta. e-mail : bisonoindracahya@gmail.com Diakses 2 April 2014.

Depdiknas, 2006.Peraturan Menteri Pendidikan Nasional Repubik Indonesia No. 22 Tahun 2006 Tentang Standar Isi untuk Satuan Pendidikan Dasar dan Menengah. Jakarta: Dirjen Dikdasmen.

Euwe Van den Berg 1991 Miskonsepsi Fisika Dan Remediasi, Salatiga Universitas Kristen Satya Wacana

Finkelstein, Noah. "Hightech Tools For Teaching Physics:The Physics Education Technology Project". Merlot journal of online learning and teaching. Vol. 2, No. 3, September 2006. 110-121

Gronlund, N. E. 1985. Constructing Achievement Test $5^{\text {th }}$ Edition.New York: Prentice Hall inc

Salam, H.dkk. "Pembelajaran Berbasis Virtual Laboratory Untuk Meningkatkan Penguasaan Konsep Pada Materi Listrik Dinamis". Proceedings of The 4th International Conference on Teacher Education; Join Conference UPI \& UPSI Bandung, Indonesia, 8-10 November 2010

Ibrahim, M. 2003. Pengembangan Perangkat Pembelajaran, Direktorat Pendidikan Lanjut Pertama, Dirjen Pendidikan Dasar dan Menengah, Departemen Pendidikan Nasional. Surabaya: Unesa University Press.

Ibrahim, M. 2005. Asesmen Berkelanjutan. Konsep dasar, Tahap pengembangan dan Contoh. Surabaya: Unesa Universty Press. 
Ibrahim, M. 2007. Pembelajaran Inkuiri. Surabaya: UNESA-University Press.

Kemendikbud.(2013). Peraturan Menteri Pendidikan Dan Kebudayaan Nomor 65 Tahun 2013 Tentang Standar Proses Pendidikan Dasar dan Menengah. Jakarta: Departemen Pendidikan dan Kebudayaan.

Kemendikbud. (2003). Undang-Undang Nomor 20 Tahun 2003 TentangSistem Pendidikan Nasional.Jakarta: Departemen Pendidikan dan Kebudayaan.

Maharta, N. 2011. Analisis Miskonsepsi Fisika SMA di bandar Lampung. Tersedia: http://www.seribd.com/doc/41470237/Jurnal -Analisis-Miskonsepsi-Fisika. Diakses 22 Maret 2013

Malik. 2011. Model Pembelajaran Inkuiri dengan Menggunakan Virtual Laboratory dan Real Laboratory untuk Meningkatkan Penguasaan Konsep dan Keterampilan Berfikir Kritis Siswa SMA pada Topik Listrik Dinamis. Tesis. Magister Pendidikan, UPI

Mulyasa, E.2011.Kurikulum Tingkat Satuan Pendidikan. Bandung: PT Remaja Rosdakarya.

Mursalin.(2013). Model Remediasi Miskonsepsi Materi Rangkaian Listrik Dengan Pendekatan Simulasi PhET.Jurnal Pendidikan Fisika Indonesia. (online, tersedia: http://journal. Unnes.ac.id, diakses 20 November 2013).

Perkins, K., (2006). PhET: Interactive Simulations for Teaching and Learning Physics. The Physic Teacher Journal.Vol. 44. (online: tersedia di: http://phet Colorado.edu. diakses 25 November 2013).

Prihatiningtyas, S., Prastowo, T., Jatmiko., (2013). Implementasi Simulasi PhET dan KIT Sederhana Untuk Mengajarkan Keterampilan Psikomotor Siswa Pada Pokok Bahasan Alat Optik.Jurnal Pendidikan IPA Indonesia. (online, tersedia: http:// journal unnes.ac.id. diakses 24 Nonember 2013).

Ratumanan, G.T., dan T, Laurens. (2006). Evaluasi Hasil Belajar yang Relevan dengan Kurikulum Berbasis Kompetensi. Surabaya: UNESA University Press.

Ratumanan, G.T., dan T, Laurens. (2006). Evaluasi Hasil Belajar yang Relevan dengan Memecahkan Problematika Belajar dan Mengajar. Bandung: CV Alfabeta.

Ridwan, M. 2012. "Keterbacaan wacana Dalam buku Teks Bahasa Dan Sastra Indonesia untuk SMP/MTs kelas VIII Karangan Wahono terbitan CV Gita Perdana Tahun
2010".Jurnal Kata (Bahasa, Sastra, dan Pembelajarannya).Vol. 1 No. $2.14-27$

Rohaeti, E. 2012."Pengembangan Lembar Kerja Siswa (LKS) mata pelajaran sains kimia untuk SMP kelasVII, VIII, dan IX.http://staff.uny.ac.id. Diakses 5 Desember 2012

Salaga, S. 2005. Konsep Belajar dan Makna Pembelajaran. Bandung: Alfabeta

Saleem Hassan, et al 1999 Misconceptions and the Certainty of Response Index (CRI), Jounal of Physic Education. 294 - 299

Sears, Zemansky, 2005. University Physics (Terjemahan), Jakarta: Erlangga

Slavin, RE. 1995. Cooperative Learning: Theory, Research, and Practice second edition. Boston: Allyn and Bacon.

Suherli Kusmana, 2008. Keterbacaan Buku Teks Pelajaran Berdasarkan Keterpahaman Bahasa Indonesia, V01. 8, No. 2. Diakses 12 Desember 2013

Suparno, Paul. 2005. Miskonsepsi \& Perubahan Konsep Pendidikan Fisika. Jakarta: PT. Grasindo.

Stanislaus, S. (2009). Pedoman Analisis Data dengan SPSS, edisi 3 cetakanpertama. Yogyakarta:Graha Ilmu.

Syaiful Sagala. 2005. Konsep dan Makna Pembelajaran. Bandung: Alfabeta.

Swandi, A., Hidayah,S.N., Irsan,J. (2014) Pengembangan Media Pembelajaran Laboratorium Virtual unruk Mengatasi Miskonsepsi Pada Materi Fisika Inti di SMAN I Binamu Jeneponto,". Jurnal Fisika Indonesia. No:52, Vol XVIII, Edisi April 2014

Tayubi, Y. R. 2005. Identifikasi Miskonsepsi Fisika pada konsep-konsep Fisika Menggunakan Certainty of Response Index (CRI). Mimbar Pendidikan 4 - 9

Wena, Made. 2009. Strategi Pembelajaran Inovatif Kontemporer. Jakarta: Bumi Aksara.

Wenning Carl J. 2005. Levels of inquiry Hierarchies of pedagogical practices and inquiry processes. Journal Of Physics Teacher Education Online: http://www.phy.ilstru.edu/jpteo.Diakses 17 $\underline{\text { Maret } 2012}$

Wolfson, Richard. 2007. Essential University Physics. San Franscisco:Adisson Wesley

Zainul, F. dan Madlazim.Pengembangan Perangkat Pembelajaran Fisika Dengan Lab. Virtual Phet Pada Materi gelombang Elektromagnetik Di SMAN 1 Kutorejo. 
Jurusan Fisika, Universitas Negeri Surabaya. Diakses 01Februari 2013

http://pasca.uns.ac.id/mod.php. Miskonsepsidalam Gaya Gesekan pada siswa dan Guru SMA Negeri 1 Surakarta dan Cara Pembetulannya. Diakses 7 Desember 2012. http://phet.colorado.edu diakses 17 Pebruari 2013. 